\title{
Children with autism spectrum disorders in the Arab Gulf countries - the Others?
}

Streszczenie: Autyzm jest zaburzeniem neurorozwojowym, które manifestuje się w obszarach związanych między innymi z relacjami społecznymi, komunikacją werbalną i niewerbalną. W ciągu ostatnich dziesięciu lat liczne kampanie społeczne na całym świecie, także w regionie Półwyspu Arabskiego, podniosły ogólny poziom świadomości na temat tego zaburzenia zarówno wśród rodziców, jak i ekspertów. Jednakże tradycyjne wierzenia i przekonania pozostają nadal istotnymi czynnikami, które kształtują zachowania związane z profilaktyką prozdrowotną i nastawieniem do kwestii związanych z szeroko pojętym zdrowiem psychicznym. Niniejsze opracowanie omawia znaczenie tych czynników, a także religii, na percepcję zaburzeń ze spektrum autyzmu w regionie państw GCC (Rady Współpracy Zatoki).

Słowa kluczowe: autyzm, niepełnosprawność, GCC, Zjednoczone Emiraty Arabskie, islam, społeczeństwo, percepcja, edukacja międzykulturowa

\section{Introduction}

In the last decade, there has been increased media attention to autism both globally and across the GCC (Gulf Cooperation Council countries - Saudi Arabia, the United Arab Emirates, Oman, Qatar, Kuwait, Bahrain). This, in turn, has increased the knowledge and awareness of the condition in the Arabian Gulf region among both parents and professionals. The first report from the region about the prevalence of autism in the community came from the United Arab Emirates (UAE) and reported a weighted prevalence of 29 per 10,000 among 3-year-olds in the UAE national population. While the rate reported from the UAE is comparable to that observed in other countries, none of the UAE children diagnosed during the study have a prior diagnosis. All of them escaped detection by the applicable paediatric healthcare oversight protocols. Parents also did not report any worrying behaviors. 
Parents and paediatricians are at the best vantage point to spot the earliest warning signs of autism. If the disorder is detected in its infancy, early intervention programs can take full advantage of the remarkable plasticity of the brain. Thus, if the signs are detected and reported by 18 months of age, intensive treatment may help ameliorate the symptoms significantly. As the burden of reporting cases falls on parents, there is the potential for lack of willingness to report certain exhibited behaviors for various reasons. Traditional beliefs have an important influence on health-related behaviors, and this has major implications on assessment and communication of health status. Religion, social perception and culture play a large role, especially when considering the diagnosis of mental health disorders.

Considering the significant economic, social and health burden caused by autism, there is limited literature on autism early diagnosis and interventions in the region. There is little existing literature that relates autism to religious, cultural and social perspectives from the Gulf, since most researchers tend to focus on psychological, pedagogical or biomedical aspects.

This paper addresses the issue of immaterial boundaries constructed by culturally influenced child upbringing practices, with special attention to how these practices and beliefs create attitudes towards disabilities such as autism.

\section{Background}

Autism (in Arabic التوحد) was first defined by Leo Kanner from Johns Hopkins University. In 1943 he received a 33-page letter from the father of a boy named Donald, describing that the boy was happiest when alone, was oblivious to his surroundings, and had a mania for spinning toys. Whenever his routine was disrupted he would exhibit temper tantrums. Donald also referred to himself in the third person and repeated words and phrases spoken to him. Kanner described Donald and ten other children in a 1943 seminal paper entitled 'Autistic Disturbances of Affective Contact'.

Clinical definitions of autism continue to evolve. The current Diagnostic \& Statistical Manual of the American Association (DSM-V) describes autism as a lifelong neurodevelopmental disorder that is characterized by impaired social interactions, impaired verbal and nonverbal communication and stereotyped, repetitive behaviors. The condition is part of a continuum of disorders collectively known as autism spectrum disorders (ASD) and is classified under the general category of pervasive developmental disorders (PDDs). As a spectrum, autism 'blurs' at the edges with disruptive behavior, 
communication disorders and intellectual disability at one end and with behaviors now thought to be neurotypical at the other.

Many researchers agree that the causes of autism are likely to be genetic, while other suspected factors are biochemical, neurological and environmental. The most commonly used treatments for children with autism are (1) Speech and Language Therapy, (2) iPhone/iPad applications, (3) Applied Behavior Analysis (ABA), (4) Picture Exchange Communication System (PECS), (5) Cognitive Behavior Therapy (CBT), (6) Occupational Therapy, (7) Holding Therapy, (8) Social Stories, (9) Equine therapy/ Therapeutic Horseback Riding, (10) Essential Fatty Acids. All of the above are legally accepted and available in UAE.

Previous chapters provided an overview of autism in GCC. The following sections will consider intangible boundaries shaped by religion, society and culture towards autistic individuals.

\section{Religious boundaries}

There is not upon the blind any guilt or upon the lame any guilt or upon the ill any guilt. And whoever obeys Allah and His messenger - He will admit him to gardens beneath which rivers flow: but whoever turns awayHe will punish him with a painful punishment.

Qur'an $(48,17)$

This chapter aims to provide a review of Islamic perspectives and Islamic philosophy on disability by examining selected texts from the Qur'an and Sunnah, referring to events from the Islamic history, and analyzing how the issue of autism is currently being addressed by the General Authority of Islamic Affairs and Endowments in UAE.

It is often difficult to distinguish between cultural and religious practices as there is an overlap between what constitutes local cultural heritage and what could be described as religious values (Al-Aoufi et al., 2012).

It does not appear that religion stands in the way of early diagnosis of autism. Islamic philosophy has a positive attitude towards those who are physically or mentally disabled. The Qur'an and the Hadith not only refer to the existence of disabilities, but also provide principles for caring for the disabled. The term 'disability' does not directly appear in the Qur'an, which uses the term 'disadvantaged people' while referring to those with special needs (Ba- 
zna \& Hatab, 2005). We can also find the generic term 'weak-minded', which according to 'tafsir' (interpretation) by Ibn Ashur (1973), comprises several groups from very young children to mentally retarded and mentally ill.

Qur'an stresses the rights of people with disabilities on several occasions. The rights mentioned in the Qur'an include the right to protection, social rights, right to treatment and rehabilitation, right to education, and marital rights (Al-Aoufi et al. 2012). The last has stirred controversy among Islamic scholars, which will be discussed in more detail later in this chapter.

The notion of the right to protection touches upon the aspect of protection of honour and respect toward disabled individuals. The Qur'anic verses emphasize that respect is a basic human right and that under-estimating others is unacceptable: 'O you who believe, let not people ridicule [other] people; perhaps they may be better than them. (...); And do not insult one another and do not call each other offensive names.' $(49,11)$. As far as social rights are concerned, those who are disabled are considered as having a rightful share (Miles, 1995). There are, however, duties which can be waived or reduced on the grounds of limited performance or the lack of mental maturity (Bazna \& Hatab, 2005). These duties include giving to charity or Zakat and performing religious rites and rituals such as wudu' and ghusl.

According to Islamic Law sanity is a prerequisite for the performance of all religious duties. The insane (majnun), the epileptic (masru'), the mentally deficient (ma'tuh) and the unconscious (maghmiyy 'alayhi) are not expected to perform any religious duties. This means that as long as the disability persists, even if the disabled performed a certain religious rite, they will earn divine reward for it. Another important right within social rights is the right to inclusion. Since disabled individuals may be isolated, withdrawn and often suffering from psychological problems such as depression and low self-esteem, it is highly encouraged in Islam to include disabled people in social occasions such as visits, marriages and other ceremonies. (Al-Aoufi et al., 2012). An example of such inclusion from the Sunnah is the story of the Prophet visiting Etban ibn Malik, a blind man from Ansar, in order to pray in the man's house and console him. Rights of treatment and rehabilitation from the Islamic perspective can be categorized into two main forms: preventive and remedial. Prevention according to Qur'an and Sunnah may amount to changing one's lifestyle or medication. Remedy can take one of the three forms: medication (including vaccination), rehabilitation, and spiritual medication (Al-Aoufi et al., 2012). Islamic Fiqh Council concluded that it is a responsibility of every Muslim to use vaccination and medication (Ghaly, 2008). 
The following Hadith from 'Sunan Abu Dawud' highlights the importance of medication:

I came to the Prophet (Peace be Upon Him) and his Companions were sitting as if they had birds on their heads. I saluted and sat down. The desert Arabs then came from here and there. They asked: 'Apostle of Allah, should we make use of medical treatment?' He replied: 'Make use of medical treatment, for Allah has not made a disease without appointing a remedy for it, with the exception of one disease, namely old age.'(AbuDawud, n.d., no. 3855).

Spiritual medication ('tahseen', meaning 'fortification') does not relate to any kind of physical medication and is solely based on performing a specific prayer. According to Muslim belief, these 'prayer supplications' constitute an effective defence against various dangers to one's health (Al-Aoufi et al., 2012).

According to Islam, the right to be educated should be granted to everyone regardless of disability. The Qur'an describes the right of education for disabled people through the following passage: He [the Prophet] frowned and turned away because there came to him a blind man, But what would make you perceive, [O Mohammed], that perhaps he might be purified, or be reminded and the remembrance would benefit him? (Qur'an, 80, 1-3). Allah rebuked Mohammad when he turned away a blind man. Therefore, one can conclude that individuals have the right not to be undermined because of their disability and that they also have the right to resources for education.

When we analyze the marital rights of the disabled, it becomes clear that there is no unanimity in this particular case, unlike in the case of above-listed rights to protection, inclusion and treatment. There has recently been an intense debate among Islamic scholars and physicians over the idea of whether the mentally and intellectually disabled (including the cases of autism) should be allowed to get married. This debate is ongoing and there are differences in opinions and interpretations. Some scholars argue that marriage can prevent the practice of inappropriate sexual behavior by mentally disabled individuals. Others see marriage as a broader responsibility beyond sexual practice, and feel that intellectually or mentally disabled people are incapable of executing such responsibility, even with guardianship.

Despite sporadic discrepancies in views on the rights of the disabled within the Islamic framework, there are two general principles of faith that shape Muslims' approaches towards disability. These include believing in the concept of 'reward and punishment' not only in terms of actions, but also in 
terms of intentions and motives behind these, and the concept of the "belief in preordination' ('qadar'), which is based on the idea that what is meant to be, will be, and what is not meant to happen, can never occur (Hasnain et al., 2008). The notion of destiny in the face of autism of one's child is well reflected in the words of the Emirati father of an autistic boy: We want the world to know about autism. God gave him this, so it is nothing to be ashamed about. The quote comes from UAE produced documentary 'As One: The Autism Project' (2014, director: Hana Makki).

The official website of the General Authority of Islamic Affairs \& Endowments, headquartered in Abu Dhabi, states that it is highly important to raise awareness regarding people with special needs by highlighting scientific facts and other various factors conducive to integrating autists into society. Awqaf stresses that it is highly recommended to admit a person with autism symptoms to a specialised centre noting that autism is of different types.

In 2013 Awqaf organized a lecture on autism for its staff. In 2017, during a press conference, Dr Mohammad Matar al Kaabi, Awqaf's Chairman, emphasised the initial indicators and results of the 'Year of Giving.' He listed a number of initiatives launched by Awqaf, including supporting the Autism Centre in Umm Al Quwain by furnishing all its classes with means of learning and rehabilitation. Another initiative aimed at autistic children was to provide buses for students' transportation for the schools of 'people with determination'.

According to Miles (2000) little has been done to investigate the impact of Islamic philosophy on Muslim practices related to working with individuals with disability.

Future research should take into account the cultural backgrounds of disabled (autistic) children, which is critical in deciding the way the parents, siblings, relatives and society respond to an autistic individual.

\section{Social and cultural boundaries}

The source of our concern for special needs people is to give each individual in our society the attention and care they deserve.

H.H. Sheikh Hamdan bin Mohammed bin Rashid Al Maktoum Chairman, Dubai Autism Center 
Despite the fact that the UAE is far ahead of most Arab nations with regards to ASD, even here there are many issues that preclude finding the exact fit or treatment for autistic children.

Alia L. Nahad (pseudonym)

Geert Hofstede has defined 'culture' as: 'the collective programming of the mind that distinguishes the members of one group or category of people from others'. (Hofstede, 1991). Through standard statistical analysis of large data sets obtained through detailed interviews and surveys during 1978-83, Hofstede determined patterns of similarities and differences between cultures from over fifty countries. From this data analysis, he developed the following five dimensions of culture: (1) Power Distance - this dimension defines the extent to which a society accepts that power is unequally distributed and whether hierarchy plays an important role; (2) Individualism - this dimension examines the importance of close long-term commitments to members of the group, be that a family, tribe or community, and whether loyalty is considered a decisive factor in decision-making; (3) Masculinity - it indicates the dominant values in society and shows whether the main social motivator is wanting to be the best (Masculine society) or liking what you do, caring for others and appreciating the quality of life (Feminine society); (4) Uncertainty Avoidance - countries exhibiting high Uncertainty Avoidance maintain rigid codes of belief and behaviour, are intolerant of unorthodox ideas, and there is an emotional need for rules in them (even if the rules never seem to work); and (5) Long Term Orientation - this dimension explains how a society has to maintain links with its own past while dealing with challenges of the present and future. Examining the UAE's culture and society through the lens of Geert Hofstede's Cultural Dimension Theory may provide some insights on how cultural and social boundaries are being constructed toward disabilities such as due to autism.

According to Hofstede's analysis of the UAE it can be stated that it is a highly hierarchical, collectivistic, uncertainty-avoiding and security-oriented society. As far as the dimension of Masculinity is concerned, Arab Emirates scored 50/50 on this dimension, which doesn't allow us to consider it clearly feminine or clearly masculine. There is no data available from the UAE on the Long Term Orientation dimension. Considering Hofstede's notion that Emirati society is a hierarchical and a collectivist one, it is easier to understand why the usage of traditional treatments of autism and other pervasive devel- 
opmental disorders in the country - such as camel milk, hijama or Epsom salt (magnesium sulfate) - tends to be more popular among many families than Applied Behavior analysis devised in the West. Treating autism with what had been known within the community for decades, if not centuries, strengthens the inclination toward security orientation, uncertainty avoidance and respect for the collective wisdom of the elderly. Hofstede's collectivism is also related to the notion of shame, embarrassment and justification. Parents who are shocked at the diagnosis of autism may instinctively resort to religion to explain the problem away, using as a safety net from social stigma. An example of these reactions is when the parents of an autistic child consider the disability to be a punishment from Allah. The danger of such an approach is that some parents tend to refuse treatment because of these beliefs (Ghaly, 2008). This refers, above all, to early intervention services (Hasnain et al, 2008). As a consequence, the child is left without adequate care and access to support services is denied or delayed. The social embarrassment of having an autistic child appears to play a crucial role in dealing with a disabled person in many families. In cases where the disability is obvious (for example in a low functioning, non-verbal autistic child) and cannot be hidden from others, parents tend to provide various explanations (Al-Aoufi et al., 2012). Such explanations include: envy ('hasad' or evil eye), using amulets (Hasnain et al., 2008), black magic, and possession by evil spirits (the Jinns). Although all of the above mentioned have their roots in Qur'an and Sunnah, it seems that the parents use it as an argument which could be easily accepted by the surrounding traditional, religious community (Al-Aoufi et al., 2012).

Cultural boundaries are directly linked to social awareness or lack thereof, social constraints and expectations. The only research related to 'autism awareness' from the UAE analyzes the knowledge and perception of childhood autism among university students (Sharif, 2016). In that study, 400 students were randomly enrolled from five universities and the questionnaire covered the major aspects of autism. It demonstrated good knowledge and perception among university students on childhood autism. Some $60 \%$ agreed that delay in early communication may be an early sign of the disorder. About $52 \%$ believed that the disorder is a pervasive one. The majority of participants $(207,69 \%)$ agreed that family history is an important factor. They also stated that vaccination, poor parenting and environmental factors are not causes of autism (Sharif, 2016) Indeed, the autism awareness level of university students seems very promising. However, it is highly recommended that a similar awareness study is conducted among women who are 
pregnant with their first child and are not yet familiar (from real life experience) with the notion of developmental milestones.

Alia L. Nahad (pseudonym), a Sharjah-based mother of an autistic boy wrote in her article called 'One Boy's Journey: Living with autism in the UAE':

My main reason for writing this article is to express my own feelings and concerns regarding how autism is viewed in the Arab world and how that has impacted my son. As the western world seems to be getting more accustomed to autism and its implications on children and their families; this is not the case in much of the Arab world. Here in the UAE it is not only strangers who have trouble dealing with ASD but even colleagues and friends of those families touched by this difficult matter. (Nahad, 2015).

Mrs. Nahad shares her personal experience: These cultural beliefs in the Arab world view autism as a stigma, which should be overlooked or even ignored if possible. When my son was very young and we visited (...) our family, they all explained some of his behaviors as being spoiled. The fact that he would lie on a couch and scream for no reason was easily "explained" as being a spoiled child. Even after we had a clear ASD diagnosis, from psychologists and specialists both in the UAE and the US, [they] have never been truly convinced.

In her analysis of the current situation in the UAE with regard to autism treatment, Mrs. Nahad concludes: The UAE has made progress; the nation has opened the Dubai Autism Center in Dubai and the Emirates Autism Center in Abu Dhabi. Dubai is the emirate with the largest support network for disabled individuals and has nine different schools, but outside of Dubai in the other six emirates each may have one center or none (Abdul-Hadi et al., 2015); this is decidedly not enough. There are waiting lists of more than 200 children trying to enter each of these facilities, which are extremely expensive. The goals of these centers are to integrate children with autism into the community through holistic approaches to intervention and therapies, while focusing their efforts on creating social awareness about autism (Dubai Autism Center website). Certainly there is a growing understanding of autism and the needs it involves (...).

\section{Conclusion}

UAE's culture in its approach towards disability in general and autism in particular reflects various elements, such as Islamic conservatism, tribalism, and western modernism. With the native population constituting less than $20 \%$ of 
the total population of the country, there is a constant intermixing of influences and trends in all spheres of life including the culture around healthcare, which again re-shapes, at least to some extent, the existing social and cultural boundaries. Thus, more research is needed in order to gain a better understanding of complex mechanisms related to disability, neurodiversity, and inclusion in the Arab Gulf region.

\section{Bibliography}

Abdul-Hadi, S., Alnaizy, L.A., Aref, B., and AlShamsi, A. 2015. Integrating people with disabilities into society in the UAE. In: Raddawi R. ed. Intercultural communication with Arabs: Studies in educational, professional and societal contexts, Heidelberg, New York: Springer, pp. 327-345.

Abu-Dawud.(n.d.). No. 3855. Translation of Sunan Abu-Dawud. Http://www. usc.edu/schools/college/crcc/engagement/resources/texts/muslim/hadith/abudawud/

Abu Dhabi e-government. 2015. Federal Law No. (29) of 2006 Concerning the Rights of People with Special Needs. https://www.abudhabi.ae/portal/ public/en/citizens/religion_and_community/special_needs/gen_info/ (1.12.2018).

Al-Aoufi, H., Al-Zyoud, N. and Shahminan, N. 2012. Islam and the cultural conceptualisation of disability. International Journal of Adolescence and Youth. 17 (4), pp. 205-219.

Alghazo, E.M. and El Naggar Gaad, E. 2004. General education teachers in the United Arab Emirates and their acceptance of the inclusion of students with disabilities. British Journal of Special Education. 31 (2), pp. 94-99.

American Psychiatric Association [APA]. 2013. Diagnostic and Statistical manual of Mental Disorders ( $5^{\text {th }}$ ed.). Arlington, VA.

Ashencaen Crabtree, S. 2007. Family responses to the social inclusion of children with developmental disabilities in the United Arab Emirates. Disability and Society. 22 (1), pp. 49-62.

Bazna, M. and Hatab, T. 2005. Disability in the Qur'an. The Islamic Alternative to Defining, Viewing, and Relating to Disability. Journal of Religion, Disability \& Health. 9 (1), pp. 5-27.

Bradshaw, K., Tennant, L., and Lydiatt, S. 2004. Special education in the United Arab Emirates: Anxieties, attitude and aspirations. International Journal of Special Education. 19 (1), pp. 45-55. 
Dardas, L., and Ahmad, M. 2014. Quality of life among parents of children with autistic disorder: a sample from the Arab World. Research in Developmental Disabilities. 35, pp. 278-287.

Dyches, T., Wilder, L., Sudweeks, R., Obiakor, F., and Algozzine, B. 2004. Multicultural issues in autism. Journal of Autism and Developmental Disorders. 34 (2), pp. 211-222.

Eapen, V., Mabrouk, A., Zoubeidi, T., \& Yunis, F. 2007. Prevalence of pervasive developmental disorders in preschool children in the United Arab Emirates. Journal of Tropical Pediatrics. 53 (3), pp. 202-205.

Elsabbagh, M., Divan, G., Koh, Y. Kim, Y.S., Kaucahli, S., Marcin, C. and Fombone, E. 2012. Global prevalence of autism and other pervasive developmental disorders. Autism Research. 5, pp. 160-179.

General Authority of Islamic Affairs and Endowments. http://www.awqaf. gov.ae/Articles/Article.aspx?SectionID=16\&RefID=1964\&lang=EN/ (20.03.2019).

Ghaly, M.M. 2008. Physical and spiritual treatment of disability in Islam: Perspectives of early and modern jurists. Journal of Religion, Disability $\mathcal{E}$ Health. 12 (2), pp. 105-143.

Hasnain, R., Shaikh, L.C., and Shanawani, H. 2008. Disability and the Muslim perspective: an introduction for rehabilitation and health care providers. Center for International Rehabilitation Research Information and Exchange, University of Buffalo, State University of New York.

Hofstede, G. 1991. Cultures and Organizations: Software of the Mind. London, McGraw-Hill.

Ibn Ashur, M. (1973). Altahrer w Altanwer. Http://www.altafsir.com/Tafasir. asp/ (15.04.2019).

Miles, M. 1995. Disability in eastern religious context: Historical perspective. Disability and Society. 10 (1), pp. 49-69.

Miles, M. 2000. Disability on a different model: Glimpse of an Asian heritage. Disability and Society. 15 (4), pp. 603-618.

Nahad, A.L. 2015. One Boy's Journey: Living with Autism in the UAE. Journal of Psychology and Behavioral Science. 2 (3), pp. 141-147.

Odrowąż-Coates, A. 2018. Soft power of language in social inclusion and exclusion and the unintended research outcomes. Language, Discourse $\mathcal{E}$ Society. 2 (6), pp. 15-30.

Pathak, S. 2012. Increasing number of autism cases in UAE demands more facilities, awareness: More professionals needed to participate in intervention programmes. http://gulfnews.com/news/uae/education/increas- 
ing-number-of-autism-cases-in-uae-demands-more-facilities-awareness-1.989465/ (30.06.2018).

Reinl, J. 2008. Arab region 'lacks' disability awareness. The National, 03 September. http://www.thenationalae/news/world/middle-east/arab-regionlacks-disability-awareness/ (10.09.2018).

Salhia, H. O., Al-Nasser, L., Taher, L.S., Al-Kahtani, A.M., and El-Metwally, A.A. 2014. Systematic review of the epidemiology of autism in Arab Gulf countries. Neurosciences. 19 (4), pp. 291-296.

Sharif, S.J., Burghaigis, L.M.T., Salah, M., Kariem, N., and Mohamed, A. 2016. Childhood autism: knowledge and perception among university students in United Arab Emirates. International Journal of Basic E Clinical Pharmacology. [S.I.], 5 (4), pp.1499-1502.

\title{
Children with autism spectrum disorders in the Arab Gulf countries - the Others?
}

\begin{abstract}
Autism is a lifelong neurodevelopmental disorder that is characterized by impaired social interactions, impaired verbal and nonverbal communication and stereotyped, repetitive behaviors. In the last decade there has been an increased media attention to autism both globally and across GCC (Gulf Cooperation Council countries), which in turn has increased the knowledge and awareness of the condition in the Arabian Gulf region among both parents and professionals. Traditional beliefs, however, leave important influences on health behaviors, which leads to implications on health communication area. Religion, spirituality and culture play a large role, especially when considering the diagnosis of mental health disorders. This paper addresses the issue of immaterial boundaries constructed by culturally bound child-upbringing practices with special attention to how these practices and beliefs create attitudes towards disabilities such as autism.
\end{abstract}

Keywords: autism, disability, GCC, United Arab Emirates, Islam, society, perception, intercultural education

Translated by Agata Wentz 